\author{
Ludmyla Babyak, Olexandra Matsyak and Vasyl Shevchuk
}

\title{
CONVERSION OF $C_{4}$ FRACTION OF HYDROCARBON PYROLYSIS PRODUCTS OVER ZVM +2 \% Zn HIGH-SILICA ZEOLITE CATALYST
}

\author{
Lviv Polytechnic N ational University, 12 St. Bandera str., 79013 Lviv, Ukraine
}

Received: August 24, 2010 / Revised: N ovember 03, 2010 / Accepted: N ovember 30, 2010

C Babyak L., Matsyak O., Shevchuk V., 2011

\begin{abstract}
Conversion of $\mathrm{C}_{4}$ fraction of hydrocarbon pyrolysis products over high-silica zeolite catalyst ZVM modified by 2 mas $\%$ of $\mathrm{Zn}$ within the temperature range of $623-823 \mathrm{~K}$ and volumetric flow rates of $1000-10000 \mathrm{~h}^{-1}$ has been investigated. The yield and chemical composition of gaseous and liquid products have been determined under various conditions. It has been shown that the initial fraction is converted almost completely (98-100\%); the yield of $\mathrm{C}_{6}-\mathrm{C}_{8}$ lower arenes is $44.2-65.4 \%$ within all investigated ranges of temperature and volumetric flow rates.
\end{abstract}

Keywords: high-silica zeolite, ethylene, propylene, lower arenes, $\mathrm{C}_{4}$ fraction, catalysate, volumetric flow rate.

\section{Introduction}

The production of lower olefins via hydrocarbons pyrolysis is constantly growing. The general productivity of pyrolysis plants in the world exceeds 100 million tons of ethylene per year. As mentioned in [1], in the nearest future the general world production of ethylene will achieve 150 million tons. At many lower olefins plants propylene is produced together with ethylene production. The yield of propylene is $40-50 \%$ of ethylene yield. In Ukraine there are two lower olefins plants: "Lukor" concern, Kalush, and refinery in Lysychansk. At the majority of lower olefins plants gasoline and gas oil fractions are used as raw materials. At the pyrolysis of the mentioned raw materials the total yield of ethylene and propylene does not exceed 50 mas \%; $\mathrm{C}_{4}, \mathrm{C}_{5}, \mathrm{C}_{6}-\mathrm{C}_{8}$ and $\mathrm{C}_{9}$ fraction, heavy products (resins), and dry gas (methane and hydrogen) are obtained as well.

The $\mathrm{C}_{6}-\mathrm{C}_{8}$ fraction contains mainly lower aromatic hydrocarbons (benzene, toluene, xylenes, and ethylbenzene). Benzene is produced from the mentioned fraction using hydrodealkylation. The benzene yield achieves $\sim 10$ mas $\%$ and essentially rises the production profitability $[2,3]$.

To achieve high techno-economic indexes of the hydrocarbons high-temperature pyrolysis, usage of other fractions, namely $\mathrm{C}_{4}$ fraction, is of great importance. The yield and composition of $\mathrm{C}_{4}$ fraction depends upon fractional and chemical compositions of the initial raw material and pyrolysis conditions. At the pyrolysis of gasoline and gas oil fractions at the temperatures of 1103 $1123 \mathrm{~K} \mathrm{C}_{4}$ fraction contains mainly butenes (1-butene, 2cis-butene, 2-trans-butene, iso-butene) and 1,3-butadiene. The total content of butenes (mas \%) is $50-52$ and the content of 1,3-butadiene is 44-48. The $\mathrm{C}_{3}, \mathrm{C}_{5}$, iso- and $n$ butanes, methylacetylene, and vinylacetylene are present in negligible quantities in $\mathrm{C}_{4}$ fraction. The fraction yield is 810 mas \% of the raw material.

In a number of countries at large petrochemical plants $\mathrm{C}_{4}$ fraction is divided into separate components and it is a main source of 1,3-butadiene, iso-butene and $n$-butenes production with further using of the obtained products for the production of caoutchouc, methyltertbutyl ether and other products of organic synthesis. The block of $\mathrm{C}_{4}$ fraction processing using extraction methods of its division is a part of large-tonnage pyrolysis plants [2, 3]. However, the implementation of such variant is highly capital and energy consuming and may be economic only using complex processing of hydrocarbon raw materials and complex application of obtained products.

At some lower olefins plants, particularly in Ukraine, $\mathrm{C}_{4}$ fraction is hydrated to butanes, which are further directed to the pyrolysis furnace. At such a way of $\mathrm{C}_{4}$ fraction processing, taking into account additional outlay on hydration, its cost is practically equal to the cost of pyrolysis raw material and is considerably lower than that of the pyrolysis main products: ethylene, propylene, and benzene. Due to the above reasons the search of a more economic method of $\mathrm{C}_{4}$ fraction processing is of great practical interest. The processes which allow to obtain valuable products at minimum possible capital and energy outlay with maximum possible usage of existing technologies and pyrolysis equipment attract a special interest. One of the ways of $\mathrm{C}_{4}$ fraction processing at industrial pyrolysis plants could be production of lower arenes and $\mathrm{C}_{2}-\mathrm{C}_{3}$ gaseous alkenes in the result of the 
conversion of butenes and butadienes presented in $\mathrm{C}_{4}$ fraction over high-silica zeolites.

A great amount of experimental and theoretical works is dedicated to the problem of catalytic conversion of gaseous hydrocarbons including $\mathrm{C}_{2}-\mathrm{C}_{4}$ alkenes over highzilica zeolite catalysts [4-8]. The regularities of alkenes conversion within the temperature range of 573-873 K and volumetric flow rates (ratio between volumetric gas consumption and catalyst volume) of $300-3000 \mathrm{~h}^{-1}$ were investigated over non-modified and modified by various metals ( $\mathrm{Zn}, \mathrm{Ga}, \mathrm{Cd}, \mathrm{Ni}, \mathrm{Co}$ ) high-silica zeolites of the ZSM type. Under corresponding conditions the alkene conversion is almost complete; the liquid catalyzate yield containing mainly lower arenes is $60-80 \%[9,10]$. During the process the catalyst is carburized and in 5-6 h its activity essentially reduces. After carbon burning with air the catalyst activity recovers [11]. The industrial processes of lower arenes production via conversion of gaseous alkanes [12] and gases containing a considerable amount of alkenes [13] are well-known. Reactors with fluidized catalyst bed are widely used in the mentioned processes.

The work [14] deals with the results concerning alkenes conversion over modified high-silica catalyst $\mathrm{ZVM}+2$ mas $\%$ of $\mathrm{Zn}$ within a wide range of volumetric flow rates (VFRs). It has been established that at $773 \mathrm{~K}$ and VFRs of 10000-20000 $\mathrm{h}^{-1}$ the high conversion of propylene and butylene $(\sim 90 \%)$, as well as high yield of the liquid catalyzate $(\sim 55 \%)$ are achieved. Under the mentioned conditions it is possible to implement the process of arenes production from gaseous alkenes of hydrocarbons cracking processing in the reactor with multi-stage location of the fixed catalyst bed. Depending upon productivity and serving cycle of the catalyst the number of stages may be from 10 to 20. In such reaction block with two reactors raw material will be supplied to separate stages by turns and regeneration of the catalysts of these stages will be done simultaneously. The implementation of the mentioned process allows to cut down capital and energy outlay as well as to reduce losses of the expensive catalyst compared with the fluidized bed reactor.

It has been shown in [15] that at $\mathrm{C}_{4}$ fraction conversion (with the joint content of butenes and 1,3butadiene of 95 mas \%) at the temperatures of 750-800 K and VFRs of 1000-2000 $\mathrm{h}^{-1}$ almost complete conversion of the initial hydrocarbons is reached and the liquid catalyzate yield is 70 mas $\%$. The liquid catalyzate contains lower arenes mainly. In order to specify the industrial process conditions the investigations of the mentioned fraction conversion were carried out at different temperatures within the wide range of VFRs over high-silica zeolite catalyst $\mathrm{ZVM}+2$ mas $\%$ of $\mathrm{Zn}$. The yield and composition of the liquid catalyzate and gaseous products were determined.

\section{Experimental}

$\mathrm{C}_{4}$ fraction (BBF) obtained from the pyrolysis of liquid hydrocarbon raw material was provided by Kalush concern "Lukor" (Ukraine). The fraction composition is as follows (mas \%): 1,3-butadiene - 44; total butenes - 51; other compounds -5 . The catalyst was obtained on the basis of ZVM zeolite (ammonium form) which was prepared at Angarsk catalyst plant (Russia). The characteristics of the used zeolite are described in [14, 16]. We obtained the hydrogen form of zeolite by calcination in the hot air and then modified it by aqueous solution of zinc acetate using infiltration method. Zinc concentration was varied from 0.5 to 2.5 mas $\%$. The catalyst activity and selectivity were determined using fractional conversion of the raw material and the yield of liquid catalyzate. The catalyst modified with 2 mas $\%$ of $\mathrm{Zn}$ had the best results with regard to activity and selectivity of desired products. In order to increase the catalyst mechanical strength we used $\gamma-\mathrm{Al}_{2} \mathrm{O}_{3}$ as a binding agent. The experiments were carried out at a laboratory plant of continuous type. The reactor was a quartz tube with internal diameter of $6 \mathrm{~mm}$ situated in the electric furnace. There was a layer of finegrained catalyst inside it. The catalyst volume was $2 \mathrm{~cm}^{3}$. The scheme of the laboratory plant, experimental procedure and analysis methods are described in [14, 17].

\section{Results and Discussion}

The experiments were carried out within the temperature range of $623-823 \mathrm{~K}_{\text {at }} 1000 \mathrm{~h}^{-1}$ and within the VFR range of $1000-10000 \mathrm{~h}^{-1}$ at $773 \mathrm{~K}$. The results are represented in the Table.

One can see from the results that under the mentioned conditions almost complete conversion (98-100\%) of unsaturated compounds of $\mathrm{C}_{4}$ fraction is achieved with the formation of liquid catalyzate and gaseous products. The yield of the liquid catalyzate is from 73.2 to 76.4 mas \%. The temperature decrease from 823 to $623 \mathrm{~K}$ insignificantly decreases the initial hydrocarbons fractional conversion and the liquid catalyzate yield. The VFR increase from 1000 to $10000 \mathrm{~h}^{-1}$ at $773 \mathrm{~K}$ has the same effect.

Similarly as at $\mathrm{C}_{2}-\mathrm{C}_{4}$ alkenes conversion over highsilica zeolite modified by metals, the obtained liquid catalyzate mainly contains lower arenes (benzene, toluene, xylenes). At the temperatures of $773-823 \mathrm{~K}$ the lower arenes content is $\sim 85 \%$ mas in the liquid catalyzate. One can see the changes in its composition depending upon reaction temperature and VFR. The increase of temperature decreases the content of aliphatic hydrocarbons and $\mathrm{C}_{9+}$ fraction, significantly increases the toluene content and to a lesser degree - the content of xylenes and benzene. The VFR increase from 1000 to $10000 \mathrm{~h}^{-1}$ and corresponding reduction of reaction time decrease the toluene content and increase the content of xylenes and benzene. 
$\frac{2}{3}$

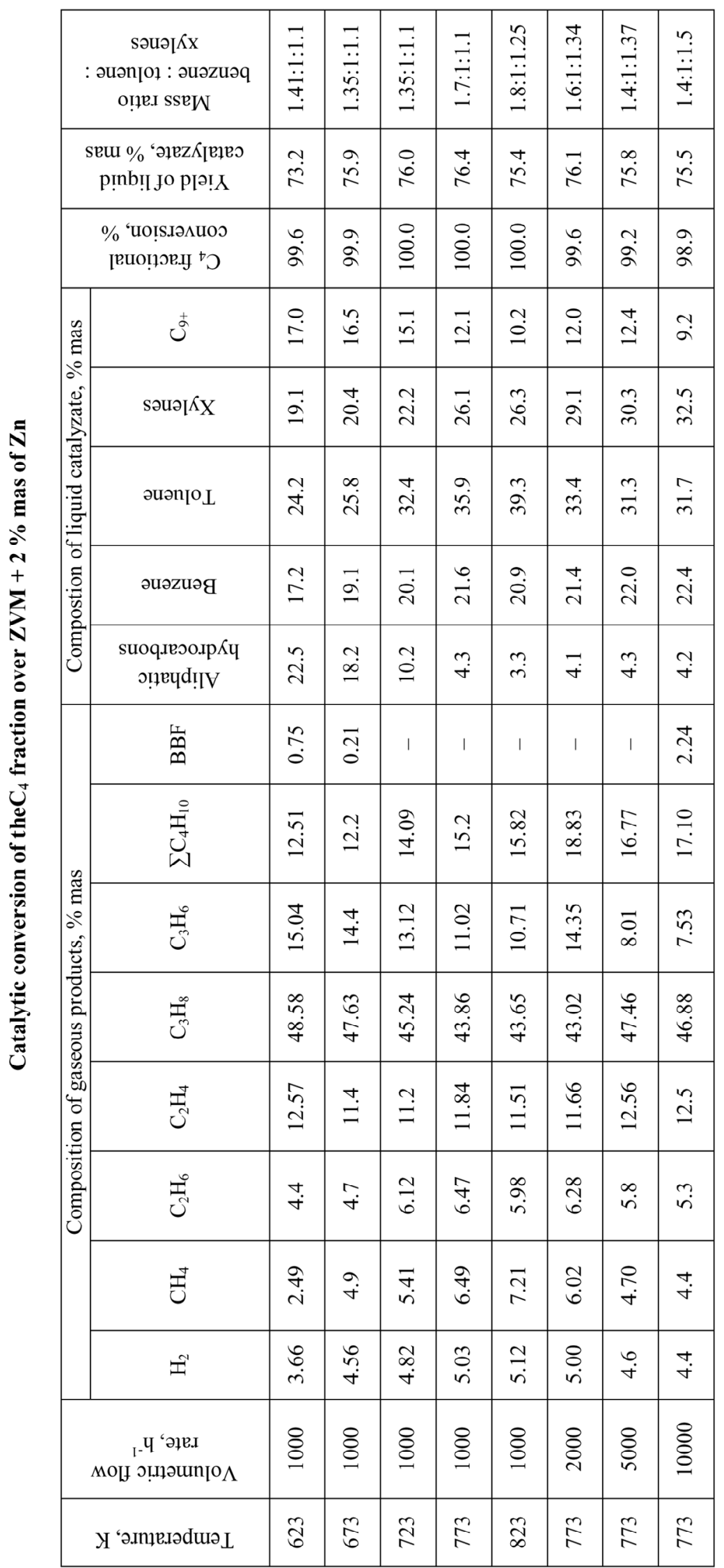


The investigated catalyst has acid activity [18] and at the mentioned temperatures the disproportionation reaction may proceed: $2 \mathrm{C}_{6} \mathrm{H}_{5} \mathrm{CH}_{3}=\mathrm{C}_{6} \mathrm{H}_{6}+\mathrm{C}_{6} \mathrm{H}_{4}\left(\mathrm{CH}_{3}\right)_{2}$. At the achievement of thermodynamic equilibrium at $700-900 \mathrm{~K}$ molar ratio of toluene: benzene: xylenes (total ortho-, para-, meta-xylene) is 0.47:0.265:0.265 (1.77:1:1) [19]. The corresponding mass ratio of the mentioned components in the equilibrium mixture is $2.09: 1: 1.36$. The toluene amount is the greatest (47 mas \%). The results from the Table show that the mass ratio differs from the equilibrium one. The toluene amount is lower compared to the equilibrium amount.

The possible reason is that at the conversion of 1,3butadiene and butenes over high-silica zeolite modified by zinc the amount of each formed lower arene and their corresponding amount in the liquid catalyzate are determined by the kinetics of formed compounds and intermediate products of their conversion. At the same time the results show the possibility of proceeding of the above mentioned disproportionation reaction. The increase of temperature increases the reaction rate and toluene content in the liquid catalyzate. At $823 \mathrm{~K}$ and VFR of $1000 \mathrm{~h}^{-1}$ the real mass ratio between the mentioned compounds is equal to the equilibrium ratio. Obviously, the change in products composition with the change of VFRs is also connected with the disproportionation reaction proceeding. At the decrease of VFR and corresponding increase of disproportionation reaction time toluene : benzene : xylenes the mass ratio verges toward equilibrium resulting in the increase of toluene content in the liquid catalyzate.

Gaseous products of $\mathrm{C}_{4}$ conversion contain hydrogen, alkanes and alkenes. The increase of temperature increases the content of hydrogen, methane, and ethane and decreases the content of propylene, propane, and butanes in the products. The increase of VFR from 1000 to $10000 \mathrm{~h}^{-1}$ leads to the minor decrease of hydrogen and methane content in the gaseous products. The propane content increases slightly. The content of other reaction products (ethylene, propylene, butanes) changes insignificantly with the change of VFR. It should be noted that at $\mathrm{C}_{4}$ fraction conversion over high-silica catalyst $\mathrm{ZVM}+2$ mas $\%$ of $\mathrm{Zn}$ the methane content in gaseous products is small $(\sim 4.5$ mas $\%$ ). The fractional conversion of initial hydrocarbons into methane is about 1 mas \%. Gaseous products mainly contain $\mathrm{C}_{2}-\mathrm{C}_{4}$ hydrocarbons out of which the total content of ethylene and propylene is $\sim 20$ mas $\%$ and the content of $\mathrm{C}_{2}-\mathrm{C}_{4}$ alkanes is $\sim 70$ mas \%.

Taking into account experimental results the industrial catalytic process of $\mathrm{C}_{4}$ fraction conversion should be implemented under atmospheric pressure at the temperature of $773 \mathrm{~K}$ and VFR of $10000 \mathrm{~h}^{-1}$. The high fractional conversion of the raw material $(98 \%)$ and high yield $\left(65.4\right.$ mas \%) of lower arenes $\left(\mathrm{C}_{6}-\mathrm{C}_{8}\right)$ are achieved under such conditions. The process may be implemented in the reactor with multi-stage location of the catalyst fixed bed. If the plant productivity is 100000 tons of $\mathrm{C}_{4}$ fraction per year $\left(\sim 12\right.$ tons per hour, $5000 \mathrm{~nm}^{3}$ of gaseous mix per hour), $\sim 0.5 \mathrm{~m}^{3}$ of the catalyst should be placed in the reaction zone of one stage. For 10-20 stages the total catalyst volume should be $5-10 \mathrm{~m}^{3}$.

At $\mathrm{C}_{4}$ fraction conversion over $\mathrm{ZVM}+2$ mas $\%$ of $\mathrm{Zn}$ under the conditions mentioned in the Table the obtained chemical compounds are similar to those produced during the high-temperature industrial pyrolysis. Therefore, the developed process allows to direct the reaction products to the general flow of hydrocarbon pyrolysis products after tube furnace. It is necessary to quench pyrolysis products before and then they may be fractionated and processed. Correspondingly, benzene will be produced from lower arenes; ethylene and propylene are desirable products of pyrolysis plant; ethane, propane and butanes will be directed to the pyrolysis furnace.

At such $\mathrm{C}_{4}$ fraction conversion at the industrial pyrolysis plants the yield of benzene is $\sim 53$ mas $\%$, ethylene and propylene -5 mas $\%$, total yield of $\mathrm{C}_{2}-\mathrm{C}_{4}$ alkanes, which are used as pyrolysis raw material - 15 mas $\%$.

Industrial implementation of the mentioned process requires relatively low capital outlays on the creation of the above described reaction block. Existing equipment is used to divide the reaction products and obtain benzene from $\mathrm{C}_{6}-\mathrm{C}_{8}$ arenes.

\section{Conclusions}

Almost complete conversion ( $98 \%$ ) of $\mathrm{C}_{4}$ fraction of hydrocarbon pyrolysis products is achieved at $773 \mathrm{~K}$ and volumetric flow rate of $10000 \mathrm{~h}^{-1}$ over high-silica zeolite catalyst ZVM modified by 2 mas \% of $\mathrm{Zn}$. The yield of lower arenes $\mathrm{C}_{6}-\mathrm{C}_{8}$ is sufficiently high $(\sim 65$ mas $\%)$. It is advisable to introduce the described process of lower arenes obtaining via conversion of $\mathrm{C}_{4}$ fraction over $\mathrm{ZVM}+2$ mas $\%$ of $\mathrm{Zn}$ into industrial production of lower olefins.

\section{References}

[1] Hsu C.and Robinson P.: Ethylene Evr. Chem. News, 2005, 83, 25.

[2] Gorislavets S., Tmenov D. and Maiorov V.: Pyrolis

Uglevodorodnogo Syrya. Naukova dumka, Kyiv 1977.

[3] Mukhina T., Barabanov N., Babash S. et al.: Pyrolis

Uglevodorodnogo Syrya. Khimiya, Moskwa 1987.

[4] Minachev Kh. and Kondratiev D.: Uspekhi Khimii, 1983, LII, 1921.

[5] Bragin O.: Uspekhi Khimii, 1981, 50, 1994.

[6] Dergachev A. and Lapidus A.: Ros. Khim. Zh., 2008, 6, 329.

[7] Brek D.: Ceolitovye Moleculyarnye Sita. Mir, Moskwa 1996.

[8] Kondratiev D., Bondarenko T. et al.: Izv. Akad. Nauk SSSR, Ser. Khim., 1991, 5, 1068.

[9] Vosmerikov A., Barbashin A. and Erofeev V.: Zh. Prikl. Khim., 1995, 68, 789. 
[10] Minachev Kh., Kazanskii V., Dergachev A. et al.: Dokl. Akad. Nauk SSSR, 1988, 303, 155.

[11] Kumar N. and Lindfors L.: Catal. Lett., 1996, 38, 239.

[12] A commercial test for "Cyclar Process": Petrol. Times, 1997, 2213, 14.

[13] Tabak S., Krambeck F. and Garwood W.: AIChI J., 1996, 32, 1526.

[14] Babyak L., Matsyak O., Shevchuk V. et al.: Chem. \& Chem. Techn., 2009, 3, 305.

[15] Babyak L., Abadjev S. and Petriv G.: Visnyk State Univ "Lvivska Polytechnika", 1994, 276, 91.

[16] Babyak L., Dzikh I., Abadjev S. and Shevchuk V.: Dep. DNTB Ukrainy, N 133- Uk93, Kyiv 1993.

[17] Matsyak O., Dzikh I., Abadjev S. and Shevchuk V.:

Ekotechn. i Resursozberegenie, 1994, 5-6, 27.

[18] Minachev Kh., Bondarenko T. and Kondratiev D.: Izv. Akad. Nauk SSSR, Ser. Khim., 1987, 3, 1225.

[19] Zhorov Yu.: Termodinamika Khimicheskikh Processov. Khimiya, Moskwa 1985.

\section{ПЕРЕТВОРЕННЯ ФРАКЦЇ̈ С ПРОДУКТІВ ПІРОЛІЗУ ВУГЛЕВОДНЕВОЇ СИРОВИНИ НА МОДИФІКОВАНОМУ} ВИСОКОКРЕМНЕЗЕМИСТОМУ ЦЕОЛІТОВОМУ КАТАЛІЗАТОРІ ЦВМ+2\% МАС. Zn

Анотація. Проведені дослідження реакиії перетворення фракиії $C_{4}$ продуктів піролізу рідкої вуглеводневої сировини на модифікованому иинком висококремнеземистому цеолітовому каталізаторі $Ц B M+2 \%$ мас. Zn за температур 623-823 Ki об ємних швидкостях 1000-10000 год-1. За різних умов перебігу реакиї визначено вихід і хімічний склад газоподібних $і$ рідких продуктів реакиії. Показано, шөо за вказаних умов досягається практично повне перетворення вихідної фракиї (98-100\%); вихід нижчих аренів $C_{6}-C_{8}$ становить 44,2-65,4\% мас.

Ключові слова: висококремнеземисті чеоліти, етилен, пропілен, нижчі арени, фракиія $C_{4}$, каталізат, об'ємна швидкicmb. 